\title{
PERSEPSI MAHASISWA TERHADAP PROSES PEMBELAJARAN KEMAHIRAN BAHASA (Mata Kuliah Kemahiran Bahasa Arab di Program Studi Sastra Arab, Fakultas Sastra, Universitas Al Azhar Indonesia)
}

\author{
Faisal Hendra \\ * Fakultas Sastra, Universitas Al-Azhar Indonesia, Jln.Sisingamangaraja, Jakarta 12110, \\ Telp.021-7244456, Fax.021-7244767, email faisal_2104@uai.ac.id
}

\begin{abstract}
Abstrak - Pengajaran bahasa Arab di program studi sastra Arab, Fakultas Sastra, Universitas Al Azhar Indonesia dimulai sejak tahun 2000 awal UAI didirikan. Dua belas tahun sudah berjalan, akan tetapi, dari tim pengajar merasa masih adanya sebuah "kegagalan" dengan tingkat keberhasilan yang dicapai, baik dari ketercapaian materi ajar maupun kemahiran berbahasa yang diharapkan.

Penelitian ini dilaksanakan untuk mendapatkan data terkait persepsi mahasiswa sastra Arab, Fakultas Sastra, UAI dalam proses pembelajaran yang dilaksanakan, yang dibagi kedalam lima bagian, yaitu: persepsi mahasiswa sastra Arab, Fakultas Sastra UAI terkait: tujuan pembalajaran kemahiran bahasa Arab, materi ajar dari mata kuliah kemahiran berbahasa, penerapan metodologi pengajaran kemahiran berbahasa, dosen pengajar mata kuliah kemahiran bahasa Arab dimata mahasiswa dan persepsi mahasiswa tentang teknik evaluasi yang digunakan oleh dosen pengajar mata kuliah kemahiran berbahasa di program Studi Sastra Arab UAI.
\end{abstract}

Hasil penelitian ini diharapkan menjadi bahan evaluasi proses pembelajaran bahasa Arab di program studi sastra Arab UAI serta pengembangan kurikulum kedepan.

Kata kunci: persepsi, proses, pembelajaran, kemahiran bahasa

Abstrct - Teaching Arabic in Arabic literature courses in the Faculty of Literature, University of Al Azhar Indonesia, started in 2000, the year UAI is established . Twelve years running, however the teaching team still detect a need of improvement in the level of success achieved, both of in teaching materials and language proficiency that are expected.

This research was conducted to obtain data on the perception of Arabic literature's students in the Faculty of Literature, UAI regarding the learning process that is being carried out, which is divided into five sections : Their perceptions concerning the goal of Arabic language proficiency, teaching materials, the application of teaching methodology, 
the course lecturers of Arabic Literature and their view on the evaluation techniques used by the course lecturers in Arabic Literature Studies UAI.

The results of this research are expected to be an evaluation process material for Arabic study in Arabic literature courses in UAI, as well as curriculum development in the future.

Keywords: perception, processes, learning, language proficiency.

\section{A. PENDAHULUAN}

Kemahiran berbahasa Arab yang empat (mendengar, berbicara, menulis dan membaca) merupakan kemahiran penting yang ingin dicapai dalam proses pembelajaran bahasa Arab di jurusan sastra Arab, Fakultas Sastra, Universitas Al Azhar Indonesia (UAI).

Pembelajaran Bahasa Arab di program studi Sastra Arab, Fakultas Sastra, Universitas Al Azhar Indonesia mengacu kepada kurikulum 2010, dimana pada kurikulum ini diarahkan kepada dua peminatan, peminatan bahasa (penerjemahan) dan peminatan Susastra (budaya). Kedua peminatan ini disesuaikan dengan tuntutan perkembangan dunia pendidikan yang sangat berharap lulusan perguruan tinggi bisa diterima oleh masayarakat keilmuannya. Atas dasar inilah program studi Sastra Arab UAI pada tahun 2010 yang lalu mencoba mendesain pengembangan kurikulumnya yang diarahkan untuk mampu mengantarkan mahasiswanya kelapangan kerja yang ingin mereka tekuni setamatnya mereka mengenyam pendidikan di Fakultas Sastra UAI.

Setelah lebih kurang 12 tahun proses pembelajaran bahasa Arab di program studi
Sastra Arab, Fakultas Sastra, Universitas al Azhar Indonesia berjalan, maka sudah saatnya dilakukan satu evaluasi yang sifatnya menyeluruh untuk melihat, menganalisis, dan menilai hasil akhir dari proses pembelajaran. Evaluasi tidak hanya dilakukan kepada mahasiswa sebagai objek diterapkannya kurikulum yang sudah berjalan. Akan tetapi juga dilakukan terhadap kinerja dosen serta metodelogi yang digunakan dalam pembelajaran sebagai pelaksana langsung proses pembelajaran di Universitas. Atas dasar inilah dilaksanakan satu penelitian. Dalam hal ini, perlu dianalisa dan diketahui seberapa jauh keberhasilan pemebelajaran bahasa Arab dilihat dari kaca mata mahasiswa terkait proses pembelajaran bahasa Arab yang dilaksanakan dikelas yang dibimbing oleh dosen, khususnya untuk mata kuliah kemahiran berbahasa Arab. Untuk mengetahui lebih lanjut tentang persepsi mahasiswa Sastra Arab, Fakultas Sastra UAI terhadap proses pembelajaran kemahiran berbahasa, khususnya mata kuliah kemahiran bahasa Arab di Program Studi Sastra Arab, Fakultas Sastra, Universitas Al Azhar Indonesia, maka diadakanlah penelitian ini.

\section{B. TEMA PENELITIAN}

Penelitian ini berjudul : PERSEPSI MAHASISWA TERHADAP PROSES PEMBELAJARAN KEMAHIRAN BAHASA (Mata Kuliah Kemahiran Bahasa Arab di Program Studi Sastra Arab, Fakultas Sastra, Universitas Al Azhar Indonesia)

\section{TUJUAN DAN MANFAAT PENELITIAN}

A. Teoretis

Mengetahui persepsi mahasiswa Sastra Arab, Fakuktas Sastra, UAI terhadap keberhasilan proses pembelajaran kemahiran bahasa Arab 
yang empat (mendengar, berbicara, menulis dan membaca) yang dibimbing oleh dosen sastra Arab dilihat dari sudut pandang tujuan pembelajaran yang ingin dicapai, materi yang diajarkan, metode pengajarannya yang diterapkan, alat bantu yang digunakan dalam proses pembelajaran dan konsep evaluasi yang dipakai untuk mengajar.

\section{B. Praktis}

Mengevaluasi konsep dan mekanisme pengajaran bahasa Arab yang selama ini diterapkan di program studi Sastra Arab, Fakultas Sastra, UAI berdasarkan persepsi mahasiswa Sastra Arab, Fakuktas Sastra, UAI terhadap keberhasilan proses pembelajaran kemahiran bahasa Arab yang dilakukan dikelas dilihat dari hasil yang didapatkan ketika diadakan Evaluasi secara menyeluruh tentang proses pembelajaran bahasa Arab di program studi Sastra Arab, Fakultas Sastra, Universitas Al Azhar Indonesia.

\section{BATASAN MASALAH DAN PERTANYAAN PENELITIAN}

Penelitian ini membatasi masalah pada persepsi mahasiswa persepsi mahasiswa Sastra Arab, Fakuktas Sastra, UAI terhadap keberhasilan proses pembelajaran kemahiran bahasa Arab khususnya untuk lima mata kuliah kemahiran berbahasa Arab yaitu: laboratorium bahasa (istima'/mendengar), muhadatsah (berbicara), qira'ah (membaca), insya (menulis), dan nahwu (tata bahasa), yang dilihat dari tujuan pembelajaran yang ingin dicapai, materi yang diajarkan, metode pengajarannya yang diterapkan, alat bantu yang digunakan dalam proses pembelajaran dan konsep evaluasi yang dipakai dalam mengajar. Batasan itu diturunkan dalam bentuk pertanyaan yang berhubungan dengan penelitian sbb:
1. Bagaimanakah persepsi mahasiswa Sastra Arab, terhadap proses pembelajaran bahasa Arab dari sudut tujuan yang ingin dicapai dalam proses pembelajaran kemahiran bahasa Arab mengacu kepada kurikulum yang digunakan di program studi Sastra Arab?

2. Bagaimanakah persepsi mahasiswa Sastra Arab, terhadap bahan ajar untuk mata kuliah kemahiran berbahasa Arab sebagai alat yang digunakan untuk mencapai tujuan pembelajaran kemahiran bahasa Arab yang diajarkan?

3. Bagaimanakah persepsi mahasiswa Sastra Arab, terhadap metode pengajaran yang diterapkan dalam mengajarkan mata kuliah kemahiran berbahasa Arab di program studi Sastra Arab?

4. Bagaimanakah persepsi mahasiswa Sastra Arab, terhadap dosen pengajar kemahiran berbahasa Arab ketika mengajarkan mata kuliah kemahiran berbahasa Arab di program studi Sastra Arab?

5. Bagaimanakah persepsi mahasiswa Sastra Arab, terhadap teknik evaluasi yang digunakan oleh dosen kemahiran berbahasa Arab ketika mengajarkan mata kuliah kemahiran berbahasa Arab di program studi Sastra Arab?

\section{KERANGKA TEORI / TINJAUAN PUSTAKA}

\section{A. Hakikat Hasil Belajar Bahasa}

Belajar merupakan suatu aktivitas yang dilakukan orang secara sadar dengan tujuan tertentu. Belajar tidak hanya dilakukan pada suatu tempat atau ruang yang dibatasi dinding-dinding seperti di kelas, tetapi dapat juga dilakukan dengan membaca, mengamati suatu benda, meniru dan lain-lain. Spears dalam Sumadi mengatakan bahwa: "Leaming to observe, to read, to immitate, to try somethings themselves, to listen, to follow direction". Belajar dapat diperoleh dengan cara mengamati, membaca, meniru, mencoba 
sesuatu dengan usaha mereka sendiri, mendengarkan, dan mengikuti pelajaran.

$$
\text { Sumadi Suryabrata, Psikologi }
$$
Pendidikan (Jakarta: Rajawali Press, 1984), h.251 "Belajar merupakan kegiatan untuk mendapatkan apa yang belum diketahui dan dengan belajar manusia dapat mengalami perubahan perubahan baik itu perilaku atau kemampuan. Perubahan yang terjadi yaitu perubahan pada aspek pengetahuan, keterampilan dan sikap, dari tidak bisa menjadi bisa, dari tidak mengerti menjadi mengerti dan dari ragu-ragu menjadi yakin menu pengalaman yang dilakukan dalam belajar".

Pendapat yang senada dikemukakan oleh Hilgard yang dikutip Abin Syamsudin "Makmun bahwa belajar itu selalu menunjukkan suatu perubahan perilaku atau pribadi seseorang berdasarkan praktek atau pengalaman tertentu”.

Efektifitas belajar mengajar dikatakan sesuai dengan hasilnya manakala tercapai kemampuan masing-masing bidang spesialisasi yang dipelajari. Hasil belajar juga merupakan kemampuan-kemampuan yang dimiliki siswa setelah menerima pengalaman belajarnya.

Menurut Tho'imah : "Hasil belajar adalah sekumpulan tindakan yang berupa pengumpulan data-data tertentu baik melalui perorangan atau suatu system atau fenomenafenomena terjadi yang kemudian data-data tersebut dianalisa secara ilmiah untuk menguji sejauh mana tujuan pengajaran tercapai sebagai kelanjutan dari pelaksanan dari suatu system".

Penilaian adalah suatu proses guru memberikan atau menentukan nilai kepada subyek berdasarkan kriteria tertentu.
Sedangkan penilaian hasil belajar adalah proses pemberian nilai terhadap hasil-hasil belajar yang dicapai siswa dengan kriteria tertentu. Menurut Good yang dikutip oleh Sa'id.

Bahasa adalah alat komunikasi massa arbitrer menggunakan simbol, digunakan oleh setiap anggota masyarakat dalam aktivitas keseharian. Bahasa Arab dapat diartikan sebagai bahasa yang mula-mula tumbuh dan berkembang di Arab. Kaum Muslimin memahami bahwa bahasa Arab adalah bahasa sumber hukum dasar yang dianutnya yaitu AIQur'an dan AI- Hadist. Oleh karena itu setiap orang muslim diharapkan dapat mempelajari bahasa Arab dengan baik.

Dalam buku AI-Arabiyyah Li-Nasyi'in disebutkan bahwa:

Bahasa Arab adalah bahasa umat Islam sejak terbitnya fajar Islam dan agama ini di muka bumi. Indikasi adanya bahasa umat Islam adalah dengan penggunaan bahasa Arab dalam kitab AIQur'an sebagai dasar hukum dan pedoman bagi seluruh umat Islam di dunia. Alasan itulah yang kemudian menyebabkan bahasa Arab dijadikan sebagai bahasa internasional baik dalam lembaga resmi maupun komunikasi sehari-hari. Selain itu bahasa Arab juga digunakan sebagai sarana penyebaran peradaban Islam ke segenap penjuru dunia.

Pengajaran bahasa Arab adalah suatu aktivitas yang menyeluruh dengan tiga tujuan:

1. Kita mampu menumbuhkan kemampuan berpikir

2. Kita mampu menumbuhkan perasaan atau emosi yang aktif terhadap bahasa Arab dan kebudayaannya

3. Kita memperoteh kemahiran bahasa tertentu

Hasil belajar bahasa Arab menurut kategori dan argumen referensi diatas, dapat diartikan sebagai semua perubahan di bidang perilaku kemampuan di bidang bahasa Arab 
mencakup menyimak, berbicara, membaca dan menulis serta perubahan dart tidak tahu menjadi tahu dan dari tidak bisa menjadi bisa menurut perubahan sikap dan perilakunya selama terjadinya proses beta jar bahasa Arab. Agar hasil bahasa Arab dapat mencapai prestasi yang diharapkan, maka diperlukan sebuah proses pembelajaran yang matang sehingga kita mampu menyerap sebanyak mungkin materi bahasa Arab yang diajarKan oleh guru atau sumber belajar lainnya. Hasil belajar bahasa Arab juga dapat berarti penguasaan seseorang dalam berbahasa Arab baik dalam aplikasi keterampilan, struktur, kosakata, dan berbicara atau keterampilan motorik lainnya. Lebih jauh dari itu adalah diharapkan kita dapat mengaplikasikan dalam bahasa komunikasi sehari-hari, seperti dalam percakapan dan mendengarkan. Adanya perubahan tingkah laku dalam penguasaan bahasa Arab itulah yang disebut sebagai perubahan selama proses belajar. Sedangkan perubahan tingkah laku dari tidak tahu menjadi tahu dan dari tidak bisa menjadi bisa adalah hasil belajamya.

\section{Persepsi}

Definisi tentang persepsi dapat dilihat dari definisi secara etimologis maupun definisi yang diberikan oleh beberapa orang ahli. Secara etimologis, persepsi berasal berasal dari kata perception (Inggris) berasal dari bahasa latin perception; dari percipare yang artinya menerima atau mengambil (Sobur, 2003:445).

Menurut kamus lengkap psikologi, persepsi adalah: (1) Proses mengetahui atau mengenali objek dan kejadian objektif dengan bantuan indera, (2) Kesadaran dari prosesproses organis, (3) (Titchener) satu kelompok penginderaan dengan penambahan arti-arti yang berasal dari pengalaman di masa lalu, (4) variabel yang menghalangi atau ikut campur tangan, berasal dari kemampuan organisasi untuk melakukan pembedaan diantara perangsang-perangsang, (5) kesadaran intuitif mengenai kebenaran langsung atau keyakinan yang serta merta mengenai sesuatu (Chaplin, 2006:358).

Menurut Leavit (dalam Sobur, 2003:445) persepsi dalam arti sempit adalah penglihatan, bagaimana cara seseorang melihat sesuatu, sedangkan dalam arti luas persepsi adalah pandangan atau pengertian yaitu bagaimana seseorang memandang atau mengartikan sesuatu.

Persepsi didefinisikan sebagai suatu proses yang menggabungkan dan mengorganisir data-data indera kita (penginderaan) untuk dikembangkan sedemikian rupa sehingga kita dapat menyadari di sekeliling kita, termasuk sadar akan diri kita sendiri (Shaleh, 2009:110).

Definisi persepsi yang diberikan oleh Desiderato (dalam Rakhmat, 1996:51) adalah pengalaman tentang objek, peristiwa, atau hubungan-hubungan yang diperoleh dengan menyimpulkan informasi dan menafsirkan pesan. Persepsi ialah memberikan makna pada stimuli inderawi (sensory stimuli). Hubungan dengan persepsi sudah jelas. Sensasi adalah bagian dari persepsi. Walaupun begitu, menafsirkan makna informasi inderawi tidak hanya melibatkan sensasi, tetapi juga atensi, ekspektasi, motivasi, dan memori.

\section{B. Hakikat Persepsi}

Manusia dalam kehidupannya selalu bersentuhan dengan berbagai macam benda, peristiwa, baik yang nyata (material) maupun tidak nyata (immaterial) misalnya: emosi, perhatian, cinta dan sebagainya sebagai objek yang dapat dilihat, dirasakan, diamati oleh panca inderanya. Dari proses penginderaan 
itulah kemudian manusia memberikan arti, penilaian maupun kesan dan inilah yang disebut persepsi.

Proses terjadinya persepsi menurut Davidoff yang dikutip Simo Walgito didahului oleh proses penginderaan oleh individu yang berwujud diterimanya stimulus oleh individu melalui alat reseptornya. Namun proses itu tidak berhenti sampai disitu saja melainkan stimulus itu diteruskan ke pusat susunan syaraf yaitu otak, dan terjadilah proses psikologis, sehingga individu menyadari apa yang ia lihat, apa yang ia dengar dan sebagainya. Individu ini mengalami persepsi.

Seseorang yang telah memiliki persepsi akan melakukan suatu tindakan sesuai dengan kesadaran yang timbul dalam dirinya dan persepsi ini selalu mempunyai hubungan dengan situasi.

Hubungan tersebut tidak sama pada setiap orang tergantung penerimaan perceptual dan lingkungan yang ada sehingga persepsi harus dipahamai sebagai suatu proses, artinya tidak dapat dimiliki hanya dapat dialami dalam aktivitasnya yang menyebabkan persepsi selalu potensial untuk berubah-ubah. Pendapat Siameto memperkuat pendapat sebelumnya bahwa persepsi bersifat relatif dan tidak absolut, artinya persepsi merupakan tatanan yang dapat dipengaruhi oleh harapan atau keinginan seseorang atau masyarakat.

Selain organ fisik indera, pembentukan persepsi dipengaruhi oleh faktor-faktor lain, diantaranya perhatian dan pengalaman yang lampau banyaknya pengalaman akan menunjang persepsi anak didik yang dapat mempengaruhi hasiJ belajamya. Sehingga persepsi seseorang terhadap sesuatu objek akan berbeda satu sama lain berdasarkan pengalaman yang diterimanya. Dari teori dan uraian persepsi diatas dapat disimpulkan bahwa hakikat persepsi siswa adalah proses seseorang untuk mengetahui hal-hal yang ada disekitamya atau lingkungannya melafui panca inderanya yang dipengaruhi pengalamannya sehingga sadar akan apa yang telah diamati yang akhimya berpengaruh terhadap sikap dan perilakunya.

\section{Hakikat Mengajar}

Menurut William H Burton: "Mengajar adalah upaya memberikan rangsang (stimulus), bimbingan, pengarahan dan dorongan kepada siswa agar terjadi proses belajar". Burton memandang pelajaran hanya sebagai bahan perangsang saja sedangkan arah yang akan dituju dengan proses belajar adalah tujuan pengajaran yang akan diketahui oleh siswa. Jadi yang terpenting dalam mengajar bukan saja upaya guru dalam menyampaikan materi, melainkan bagaimana siswa dapat mempelajari materi pelajaran sesuai dengan tujuan. Hal ini berarti bahwa usaha guru hanya merupakan serangkaian peristiwa yang dapat mempengaruhi kita untuk belajar. Disini peran guru berubah, guru bukan hanya berperan sebagai penyampai informasi melainkan sebagai "director and facilitator' yaitu pengarah dan pemberi fasilitas untuk terjadinya proses belajar. Sedangkan menurut Mohammad Uzer Usman dalam bukunya "Menjadi Guru Profesional", menyatakan bahwa: Mengajar pada prinsipnya adalah membimbing siswa dalam kegiatan belajarmengajar atau mengandung pengertian bahwa mengajar merupakan suatu usaha, mengorganisasi Iingkungan dalam hubungannya dengan anak didik dan bahan pengajaran yang menimbulkan proses belajar.

Pendapat tersebut sejalan dengan Alvin W. Howard yang mendefinisikan mengajar adalah:"Suatu aktivitas untuk mencoba menolong, membimbing seseorang untuk mendapatkan, mengubah, atau 
mengembangkan skill (kemampuan), ideals (Gita-Gita), appreciations (penghargaan) dan knowledge (pengetahuan)".

\section{Hakikat Kompetensi Mengajar}

Kompetensi atau competence menurut Purwadarminto W.J.S dalam kamus bahasa berarti "kewenangan, kekuasaan untuk menentukan dalam merumuskan sesuatu". Sedangkan Mohammad Uzer Usman menyatakan bahwa: "kompetensi berarti suatu hal yang menggambarkan kualifikasi atau kemampuan seseorang, baik yang kualitatif maupun yang kuantitatif'. Selanjutnya menurut Piet dan Alaida Sahertian, kompetensi merupakan "kemampuan melaksanakan sesuatu yang diperoleh melalui pendidikan dan latihan yang bersifat kognitif, afektif dan performance. Mendiknas juga merumuskan kompetensi dalam sebuah keputusannya No. 045/U/2002 bahwa kompetensi adalah seperangkat tindakan cerdas, penuh tanggung jawab, yang dimiliki oleh seseorang sebagai syarat kemampuan untuk mengerjakan tugas-tugas di bidang pekerjaan tertentu”.

Menurut pengertian tersebut seorang dikatakan kompeten jika ia memiliki kemampuan dalam mengembangkan pengetahuan yang telah ia peroleh melalui pendidikan dan latihan serta mampu menjawab tantangan yang datang dari luar dirinya. Sumber daya yang ada pada dirinya tersebut dipergunakan untuk mengembangkan sumber daya pribadi yang lain.

Kompetensi mengajar juga merupakan "Kemampuan dasar yang dapat mengimplikasikan apa yang seharusnya dilakukan seorang guru dalam melaksanakan tugasnya" .Yang berarti bahwa kompetensi mengajar adalah kemampuan yang harus dimiliki seorang guru dalam menyampaikan materi pelajaran kepada anak didik yang semua itu merupakan suatu hal yang menggambarkan kuatifikasi ataupun kemampuan seorang guru, baik secara kuantitatif serta kualitatif yang diberikan guru yang bersangkutan. Pengembangan kompetensi keguruan bertolak dari pengembangan kompetensi dasar, yaitu kompetensi kepribadian, kompetensi sosial dan kompetensi profesional.

\section{E. Persepsi Terhadap Kompetensi Mengajar}

Berbagai upaya dapat dilakukan untuk menentukan tingkat kompetensi mengajar guru, ini dapat dilakukan dengan menggunakan berbagai sumber, metode dan berbagai kriteria lain seperti dari teman sejawat, departemen pendidikan, pimpinan,catatan administrator serta dari siswa. Tetapi pada prinsipnya sumber informasi haruslah orang-orang yang berkesempatan

\section{METODE PENELITIAN}

\section{A. Pendekatan Penelitian}

Penelitian ini dilakukan dengan menggunakan pendekatan kualitatif. Populasi target penelitian ini adalah seluruh mahasiswa yang terdaftar aktif di program studi Sastra yang sedang mempelajari mata kuliah kemahiran berbahasa Arab, Fakultas Sastra, Universitas Al Azhar Indonesia, serta dosen pengajar kemahiran berbahasa yang mengajar di jurusan sastra Arab, Fakultas Sastra, Universitas Al Azhar Indonesia

\section{B. Subjek Penelitian}

Dalam penelitian ini, karakteristik subjek adalah Sebagai berikut :

Subjek penelitian ini adalah dosen pengampu mata kuliah kemahiran berbahasa di program studi Sastra Arab, Fakultas Sastra, Universitas 
Al Azhar Indonesia, khususnya untuk mata kuliah kemahiran berbahasa (kemahiran mendengar, berbicara, membaca dan menulis). Serta mahasiswa dilingkungan di program studi Sastra Arab, Fakultas Sastra, yang berjumlah lebih kurang 75 orang yang terdaftar aktif untuk tahun akademik 20112012 ini .

\section{Tahapan penelitian}

Dalam penelitian terdapat dua tahap penelitian, tahap persiapan penelitian, tahap pelaksanaan penelitiaan

\section{Teknik Pengumpulan Data}

Dalam penelitiaan ini, peneliti menggunakan dua teknik pengumpulan data, yaitu wawancara dan observasi

\section{E. Alat Bantu pengumpulan Data}

Menurut Poerwandari (1998) penulis sangat berperan dalam seluruh proses penelitian, mulai dari memilih topik, mendeteksi topik tersebut, mengumpulkan data, hingga analisis, menginterprestasikan dan menyimpulkan hasil penelitian.

Dalam mengumpulkan data-data penulis membutuhkan alat Bantu (instrumen penelitian). Dalam penelitian ini peneliti menggunakan 3 alat bantu, yaitu : Pedoman wawancara, Pedoman Observasi dan Angket yang ditulis berdasarkan urutan kebutuhan peneliti untuk mendapatkan keotentikan jawaban yang disampaikan oleh subjek.

\section{F. Keabsahan dan Keajegan Penelitian}

Studi kasus ini menggunakan penelitian pendekatan kualitataif. Yin (2003) mengajukan empat kriteria keabsahan dan keajegan yang diperlukan dalam suatu penelitian pendekatan kualitatif. Empat hal tersebut adalah Keabsahan Konstruk (Construct validity), Keabsahan Internal (Internal validity), Keabsahan internal, Keabsahan Eksternal (Eksternal validity)

\section{G. Teknik Analisis Data}

Marshall dan Rossman mengajukan teknik analisa data kualitatif untuk proses analisis data dalam penelitian ini. Dalam menganalisa penelitian kualitatif terdapat beberapa tahapan-tahapan yang perlu dilakukan (Marshall dan Rossman dalam Kabalmay, 2002), diantaranya: Mengorganisasikan Data, Pengelompokan berdasarkan Kategori, Tema dan pola jawaban, Menguji Asumsi atau Permasalahan yang ada terhadap Data, Mencari Alternatif Penjelasan bagi Data dan Menulis Hasil Penelitian.

\section{PEMBAHASAN HASIL PENELITIAN}

Persepsi Mahasiswa Terhadap Proses Pembelajaran Kemahiran Berbahasa Arab di Program Studi Sastra Arab, Fakultas Sastra, Universitas Al Azhar Indonesia 


\section{Profil Responden}

Tabel 1: Profil responden penelitian berdasarkan umur, jenis kelamin dan angkatan

\begin{tabular}{|c|c|c|c|}
\hline No & \multicolumn{2}{|c|}{ Pernyataan } & \multirow{2}{*}{$\begin{array}{l}\text { Jumlah } \\
4 \text { orang }\end{array}$} \\
\hline & \multirow[t]{6}{*}{ Umur } & 17 tahun & \\
\hline & & 18 tahun & 6 orang \\
\hline & & 19 tahun & 9 orang \\
\hline & & 20 tahun & 18 orang \\
\hline & & 21 tahun & 15 orang \\
\hline & & 22 tahun & 12 orang \\
\hline & \multirow[t]{2}{*}{ Jenis Kelamin } & Laki-laki & 27 orang \\
\hline & & Perempuan & 37 orang \\
\hline & \multirow[t]{5}{*}{ Angkatan } & 2008 & 11 orang \\
\hline & & 2009 & 14 orang \\
\hline & & 2010 & 14 orang \\
\hline & & 2011 & 10 orang \\
\hline & & 2012 & 15 orang \\
\hline
\end{tabular}

Tabel 2: Persepsi mahasiswa terhadap pernyataan bahwa mahasiswa memahami dan menyadari sepenuhnya tentang tujuan dan arah pembelajaran MK kemahiran bahasa Arab

\begin{tabular}{|l|l|l|l|l|l|}
\hline & & Frekuensi & Persentase & Persentase valid & Persentase kumulatif \\
\hline Valid & Setuju & 50 & 78.1 & 78.1 & 78.1 \\
\hline & $\begin{array}{l}\text { Tidak } \\
\text { Berpendapat }\end{array}$ & 4 & 6.2 & 6.2 & 84.3 \\
\hline & Tidak Setuju & 10 & 15.7 & 15.7 & 100.0 \\
\hline & Total & 64 & 100.0 & 100.0 & \\
\hline
\end{tabular}


Mahasiswa yang dijadikan responden dalam penelitian ini berjumlah sebanyak 64 orang dari 75 orang mahasiswa yang terdaftar aktif di sastra Arab UAI untuk tahun ajaran 20112012 yang tersebar disemester yang berbeda mulai dari semester satu, tiga, lima, dan tujuh bahkan ada beberapa orang sedang mahasiswa semester sembilan, dan dari angkatan mahasiswa yang dijadikan sample, mereka tersebar dari angkatan yang berbeda, mulai dari angkatan 2007, angkatan 2008, angkatan 2009, angkatan 2010, angkatan 2011 dan angkatan 2012 yang merupakan angkatan baru untuk tahun 2012 ini. Dari masing-masing kelas dan angkatan dipilih secara acak sebagai sampel penelitian. Jadi total seluruh mahasiswa sastra Arab yang dijadikan responden berjumlah 64 orang.

\section{Berikut analisa penelitian terkait persepsi mahasiswa tentang tujuan pembelajaran kemahiran berbahasa di program studi Sastra Arab UAI}

Dari tabel diatas didapati bahwa mayoritas mahasiswa sastra arab UAI menyadari sepenuhnya tentang tujuan dan arah pembelajaran MK kemahiran bahasa arab yang di fokuskan kepada empat kemahiran berbahasa, mendengar, berbicara, membaca dan menulis yang digunakan untuk membekali mereka kepada profesi yang diharapkan lahir dari lulusan sastra arab UAI yaitu sebagai seorang penerjemah. Penguasaan kemahiran berbahasa ini sebagai modal awal mahasiswa sebelum mereka mengambil mata kuliah penerjemahan yang merupakan ciri khas sastra arab UAI. Bentuk pemahaman mahasiswa tentang tujuan dan arah pembelajaran bahasa arab di UAI tergambar dari hasil observasi yang dilakukan dimana 50 orang atau sekitar $78.1 \%$ menyatakan setuju bahwasanya mereka memahami dan menyadari tentang tujuan dan arah pembelajaran MK kemahiran bahasa arab di UAI, dan empat orang atau $6.2 \%$ tidak menyatakan pendapatnya, sementara 10 orang atau $15.7 \%$ tidak setuju dengan pernyataan Mahasiswa sastra Arab UAI memahami dan menyadari sepenuhnya tentang tujuan dan arah pembelajaran MK kemahiran bahasa Arab di UAI. Hal ini menurut analisa peneliti berdasarkan wawancara yang dilakukan, jumlah $10 \%$ ini mayoritas berasal dari mahasiswa tahun pertama yang belum menyadari sepenuhnya arah dan tujuan kemana pemebelajaran bahasa arab di UAI dilakukan. Saat penelitian ini dilakukan mahasiswa semester satu sastra Arab UAI sedang dalam persiapan ujian tengah semester, semester ganjil 2012-2013. 
Tabel 3: Persepsi mahasiswa terhadap pernyataan bahwa tujuan pembelajaran sudah terarah dan sesuai dengan standar yang diharapkan oleh mahasiswa

\begin{tabular}{|l|l|l|l|l|l|}
\hline & & Frekuensi & Persentase & Persentase valid & Persentase kumulatif \\
\hline Valid & Setuju & 45 & 70.3 & 70.3 & 70.3 \\
\hline & $\begin{array}{l}\text { Tidak } \\
\text { Berpendapat }\end{array}$ & 3 & 4.6 & 4.6 & 74.9 \\
\hline & Tidak Setuju & 17 & 25.1 & 25.1 & 100.0 \\
\hline & Total & 64 & 100.0 & 100.0 & \\
\hline
\end{tabular}

Tabel 4: Persepsi mahasiswa terhadap pernyataan bahwa tujuan pembelajaran

disiapkan untuk menjawab tantangan lulusan di lapangan kerja nanti

\begin{tabular}{|l|l|l|l|l|l|}
\hline & & Frekuensi & Persentase & Persentase valid & Persentase kumulatif \\
\hline Valid & Setuju & 40 & 62.5 & 62.5 & 62.5 \\
\hline & $\begin{array}{l}\text { Tidak } \\
\text { Berpendapat }\end{array}$ & 7 & 10.9 & 10.9 & 73.4 \\
\hline & Tidak Setuju & 17 & 26.6 & 26.6 & 100.0 \\
\hline & Total & 64 & 100.0 & 100.0 & \\
\hline
\end{tabular}

Dari table diatas didapati bahwa sebanyak 45 orang mahasiswa atau sekitar $70.3 \%$ menyatakan bahwa pembelajaran mata kuliah kemahiran bahasa arab di UAI sudah terarah dan sesuai dengan standar yang diharapkan oleh mahasiswa. Jumlah 45 orang ini cukup besar mengingat pembelajaran bahasa arab di UAI betul-betul diarahkan kepada kemahiran berbahasa untuk disiapkan menjadi seorang penerjemah. Pemahaman arah dan tujuan ini telah disosialisasikan kepada mahasiswa sejak dini tentang pentingnya kemahiran berbahasa sebagai modal awal untuk menjadi seorang penerjemah. tiga orang atau sekitar $4.6 \%$ tidak menyatakan pendapatnya. Sementara 17 orang atau sekitar $25.1 \%$ menyatakan tidak setuju dengan pernyataan tujuan pembelajaran MK kemahiran Bahasa Arab sudah terarah dan sesuai dengan standar yang diharapkan oleh mahasiswa sastra Arab UAI. Menurut analisa peniliti 17 orang mahasiswa yang berpendapat seperti ini tentunya memiliki alasan masingmasing. Terjadi kegamangan khususnya mahasiswa semester akhir sastra arab UAI sebelum mereka tamat dari UAI, ketika mereka mencoba intropeksi diri dari kemahiran berbahasa arab yang mereka miliki dimana kebutuhan pasar (pengguna) lebih besar dari penguasaan mereka terhadap kemahiran yang mereka yang kuasai.

Dari tabel 4 diatas didapati bahwa sebanyak 40 orang mahasiswa atau sekitar 62.5\% mahasiswa setuju dengan pernyataan yang menyatakan bahwa tujuan pembelajaran MK 
kemahiran bahasa Arab di UAI disiapkan untuk menjawab tantangan lulusan di lapangan kerja nanti, karena memang kurikulum sastra arab UAI didesain untuk mengantarkan.

Tabel 5: Persepsi mahasiswa terhadap pernyataan bahwa secara umum, materi MK kemahiran Bahasa Arab di UAI mudah dipahami

\begin{tabular}{|l|l|l|l|l|l|}
\hline & & Frekuensi & Persentase & Persentase valid & Persentase kumulatif \\
\hline Valid & Setuju & 53 & 82.8 & 82.8 & 82.8 \\
\hline & $\begin{array}{l}\text { Tidak } \\
\text { Berpendapat }\end{array}$ & 3 & 4.7 & 4.7 & 87.5 \\
\hline & Tidak Setuju & 8 & 12.5 & 12.5 & 100.0 \\
\hline & Total & 64 & 100.0 & 100.0 & \\
\hline
\end{tabular}

mahasiswa ke lapangan kerja yang di inginkan, apalagi sebelum mahasiswa tamat dari UAI mereka dibekali dengan praktek kerja lapangan (PKL) ke institusi dan lembaga yang bergerak di bidang penerjemahan. Pengalaman mahasiswa di PKL mengantarkan mereka kepada kenyataan dilapangan yang menghendaki penguasaan kemahiran berbahasa yang empat harus di kuasai karena tanpa penguasaan yang cukup lulusan sastra arab UAI tidak akan dilirik (digunakan) oleh pengguna lulusan atau masyarakat. Sebanyak 7 orang atau sekitar $10.9 \%$ tidak menyatakan pendapatnya. Sementara 17 orang atau sekitar 26.6\% tidak setuju ketika dinyatakan bahwa tujuan pembelajaran MK kemahiran bahasa Arab di UAI disiapkan untuk menjawab tantangan lulusan di lapangan kerja nanti. Hal ini menurut analisa peneliti disebabkan oleh input yang masuk ke UAI cukup beragam, dengan keberagaman ini menyebabkan tingkat penguasaan mahasiswa terhadap kemahiran berbahasa sebagai modal dasar untuk menekuni dunia penerjemahan sebagai jurusan UAI juga beragam. Ketidaksiapan mereka dalam penguasaan kemahiran berbahasa khusus untuk mahasiswa semester akhir menyebabkan kegamangan mereka menghadapi tantangan dunia kerja setelah tamat nanti.

\section{Persepsi mahasiswa tentang materi mata kuliah kemahiran berbahasa bahasa Arab di program studi Sastra Arab}

Dari table diatas didapati bahwa sebanyak 53 orang mahasiswa atau sekitar $82.8 \%$ menyatakan bahwa secara umum, materi MK kemahiran Bahasa Arab di UAI mudah dipahami, hal ini disebabkan sastra arab UAI menggunakan kurikulum dan bahan ajar yang terintegrasi antara satu matakuliah kemahiran berbahasa dengan kemahiran berbahasa yang lain sehingga mahasiswa merasa ada singkronisasi materi antar matakuliah sejenis. 3 orang mahasiswa atau sekitar $4.7 \%$ tidak menyatakan pendapatnya. Sementara 8 orang 
mahasiswa atau sekitar $12.5 \%$ tidak setuju dengan pernyataan bahwa secara umum, materi MK kemahiran Bahasa Arab di UAI mudah dipahami, hal ini menurut analisa peneliti disebabkan karena input yang masuk ke UAI beragam tidak berasal dari satu latar belakang dimana ada beberapa mahasiswa mempelajari bahasa arab pertama kali di UAI, keberagaman latar belakang ini menyebabkan berbeda pula penguasaan mereka terhadap kemahiran berbahasa yang diajarkan sehingga muncullah perasaan sulit dalam mempelajari materi matakuliah kemahiran yang diajarkan bagi sebagian kecil mahasiswa.

Tabel 6: Persepsi mahasiswa terhadap pernyataan bahwa materi yang diajarkan sesuai dengan realita bahasa harian mahasiswa

\begin{tabular}{|l|l|l|l|l|l|}
\hline & & Frekuensi & Persentase & Persentase valid & Persentase kumulatif \\
\hline Valid & Setuju & 45 & 70.3 & 70.3 & 70.3 \\
\hline & $\begin{array}{l}\text { Tidak } \\
\text { Berpendapat }\end{array}$ & 6 & 9.4 & 9.4 & 79.7 \\
\hline & Tidak Setuju & 13 & 20.3 & 20.3 & 100.0 \\
\hline & Total & 64 & 100.0 & 100.0 & \\
\hline
\end{tabular}

Dari table diatas didapati bahwa 45 orang mahasiswa atau sekitar $70.3 \%$ setuju ketika dinyatakan bahwa materi yang diajarkan di MK Bahasa Arab sesuai dengan realita bahasa harian mahasiswa. Pernyataan ini berangkat dari penggunaan buku bahasa arab Al Arabiah Baina Yadaika tiga jilid yang digunakan. Buku ini sifatnya tematik yang dibagi kedalam bentuk bahan percakapan, bahan bacaan yang didesain dengan judul-judul yang dekat dengan keseharian mahasiswa. Secara tidak langsung bahasa yang digunakan dipraktekan oleh mahasiswa baik antara sesama mahasiswa maupun antara mahasiswa dengan dosen yang mengajar. Materi-materi ini menjadi motivasi tersendiri bagi mahasiswa untuk berani berbicara sesuai dengan tema yang dipelajari. 6 orang mahasiswa atau sekitar 9.4\% tidak menyatakan pendapatnya. Sementara 13 orang mahasiswa atau sekitar $20.3 \%$ tidak setuju dengan pernyataan bahwa materi yang diajarkan di MK Bahasa Arab sesuai dengan realita bahasa harian mahasiswa. Hal ini bisa dipahami sebagai bukti bahwa input yang beragam yang masuk ke sastra arab UAI sangat mempengaruhi penguasaan mereka kepada kemahiran berbahasa yang diharapkan walaupun sudah menggunakan bahan ajar yang ideal digunakan untuk meningkatkan kemampuan mahasiswa dalam kemahiran berbahasa.

IV. Berikut analisa penelitian terkait persepsi mahasiswa tentang penerapan metodologi pengajaran kemahiran berbahasa oleh dosen pengampu mata kuliah kemahiran berbahasa bahasa Arab di program studi Sastra Arab 
Tabel 7: Persepsi mahasiswa terhadap pernyataan bahwa pengajaran

kemahiran bahasa Arab di UAI telah diajarkan secara sistematis

\begin{tabular}{|l|l|l|l|l|l|}
\hline & & Frekuensi & Persentase & Persentase valid & Persentase kumulatif \\
\hline Valid & Setuju & 57 & 89.1 & 89.1 & 89.1 \\
\hline & $\begin{array}{l}\text { Tidak } \\
\text { Berpendapat }\end{array}$ & 0 & 0 & 0 & 89.1 \\
\hline & Tidak Setuju & 7 & 10.9 & 10.9 & 100.0 \\
\hline & Total & 64 & 100.0 & 100.0 & \\
\hline
\end{tabular}

Dari table diatas didapati data bahwa 57 orang mahasiswa atau sekitar $89.1 \%$ mahasiswa setuju dengan pernyataan yang menyatakan bahwa pengajaran MK kemahiran bahasa Arab di UAI telah diajarkan secara sistematis. Menurut analisa peneliti pernyataan mahasiswa ini dilatarbelakangi oleh sistem perkuliahan yang didesain sedemikian rupa dengan menggunakan metode dan alat bantu yang sesuai dengan bahan ajar yang diajarkan. Sistem perkuliahan di UAI mencoba untuk menyeimbangkan antara hak dan kewajiban yang harus dijalankan secara seimbang antara dosen dan mahasiswa. Sebagai contoh 3 SKS yang diajarkan, dalam pelaksanaannya berarti 3 SKS tatap muka dikelas, 3 SKS pemantapan melalui diskusi mahasiswa diluar jam kuliah dan 3 SKS berikutnya melalui belajar mandiri masing-masing mahasiswa dirumah. Penerapan sistem ini memberikan dampak yang signifikan dalam penguasaan kemahiran berbahasa di sastra arab di UAI. Sementara 7 orang mahasiswa atau sekitar 10.9\% mahasiswa tidak setuju dengan pernyataan yang menyatakan bahwa pengajaran MK kemahiran bahasa Arab di UAI telah diajarkan secara sistematis.

Tabel 8: Persepsi mahasiswa terhadap pernyataan bahwa dosen mengajar sesuai dengan Satuan Acuan Perkuliahan yang sudah ditetapkan diawal perkuliahan

\begin{tabular}{|l|l|l|l|l|l|}
\hline & & Frekuensi & Persentase & Persentase valid & Persentase kumulatif \\
\hline Valid & Setuju & 57 & 89.1 & 89.1 & 89.1 \\
\hline & $\begin{array}{l}\text { Tidak } \\
\text { Berpendapat }\end{array}$ & 3 & 4.7 & 4.7 & 93.8 \\
\hline & Tidak Setuju & 4 & 6.2 & 6.2 & 100.0 \\
\hline & Total & 64 & 100.0 & 100.0 & \\
\hline
\end{tabular}


Dari table diatas didapati data bahwa 57 orang mahasiswa atau sekitar $89.1 \%$ mahasiswa merupakan jumlah mayoritas menyatakan setuju dengan pernyataan yang menyatakan bahwa dosen MK kemahiran bahasa Arab mengajar sesuai dengan Satuan Acuan Perkuliahan yang sudah ditetapkan diawal perkuliahan. Pernyataan ini sejalan dengan tuntutan perkuliahan di UAI karena dosen sebelum mengajar harus merevisi SAP dari matakuliah yang diajarkan dan mensosialisasikan materi yang akan diajarkan kepada mahasiswa yang diajar. Tiga orang mahasiswa atau sekitar $4.7 \%$ mahasiswa tidak menyatakan pendapatnya. Sementara 4 orang mahasiswa atau sekitar 6.2\% mahasiswa tidak setuju dengan pernyataan yang menyatakan bahwa dosen MK kemahiran bahasa Arab mengajar sesuai dengan Satuan Acuan Perkuliahan yang sudah ditetapkan diawal perkuliahan.

\section{Berikut analisa penelitian terkait persepsi mahasiswa tentang dosen/pengajar mata kuliah kemahiran berbahasa bahasa Arab di program studi Sastra Arab}

Tabel 9: Persepsi mahasiswa terhadap pernyataan bahwa dosen mata kuliah

kemahiran bahasa Arab dekat dan akrap dengan mahasiswa yang diajar

\begin{tabular}{|l|l|l|l|l|l|}
\hline & & Frekuensi & Persentase & Persentase valid & Persentase kumulatif \\
\hline Valid & Setuju & 47 & 73.4 & 73.4 & 73.4 \\
\hline & $\begin{array}{l}\text { Tidak } \\
\text { Berpendapat }\end{array}$ & 2 & 3.1 & 3.1 & 76.5 \\
\hline & Tidak Setuju & 15 & 23.4 & 23.4 & 100.0 \\
\hline & Total & 64 & 100.0 & 100.0 & \\
\hline
\end{tabular}

Dari table diatas didapati data bahwa 47 orang mahasiswa atau sekitar $73 \%$ menyatakan setuju ketika dinyatakan bahwa dosen MK kemahiran bahasa di sastra Arab UAI dekat dan akrap dengan mahasiswa yang diajar. Pernyataan ini sejalan dengan konsep pendidikan yang dikembangkan di UAI dimana konsep kekeluargaan menjadi sebuah keharusan yang dikembangkan oleh civitas akademika UAI, baik mahasiswa dengan mahasiswa maupun antara dosen dan mahasiswa. Dua orang mahasiswa atau sekitar
$3.1 \%$ tidak menyatakan pendapatnya, sementara 15 orang atau sekitar $23.4 \%$ mahasiswa merasa tidak begitu dekat dan akrap dengan para dosen yang mengajar, hal ini bisa disebabkan oleh dosen sendiri atau bisa jadi adanya rasa sungkan dari mahasiswa untuk dekat dengan dosen diluar perkuliahan yang berjalan. Disisi lain ada satu angkatan mahasiswa khususnya angkatan 2012 belum begitu lama berintegrasi dengan para dosen yang mengajar, karen saat penelitian ini dilaksanakan khusus angkatan 2012 baru 
belajar selama 2 bulan, bisa jadi atas dasar

kondisi inilah kondisi ini didapatkan.

Tabel 10: Persepsi mahasiswa terhadap pernyataan bahwa dosen mata kuliah kemahiran bahasa Arab mengajar sesuai dengan jadwal dan waktu yang ditentukan

\begin{tabular}{|l|l|l|l|l|l|}
\hline & & Frekuensi & Persentase & Persentase valid & Persentase kumulatif \\
\hline Valid & Setuju & 31 & 48.5 & 48.5 & 48.5 \\
\hline & $\begin{array}{l}\text { Tidak } \\
\text { Berpendapat }\end{array}$ & 5 & 7.8 & 7.8 & 56.2 \\
\hline & Tidak Setuju & 28 & 43.7 & 43.7 & 100.0 \\
\hline & Total & 64 & 100.0 & 100.0 & \\
\hline
\end{tabular}

Dari table diatas didapati data bahwa 31 orang mahasiswa atau sekitar $48.5 \%$ mahasiswa menyatakan setuju dengan pernyataan yang menyatakan bahwa dosen MK kemahiran bahasa Arab mengajar sesuai dengan jadwal dan waktu yang ditentukan. Menurut analisa peneliti persepsi mahasiswa yang menyatakan bahwa dosen kemahiran berbahasa arab mengajar sesuai jadwal yang ditentukan merupakan jawaban yang sebenarnya dan sejujurnya. Dengan jumlah hanya sekitar 31 orang yang menyatakan setuju dari 64 mahasiswa yang dibagikan angket membuktikan kalau tidak semua mahasiswa menilai para dosen mengajar sesuai dengan waktu yang sudah ditentukan (28 orang). Jumlah ini masuk kategori sangat besar karena kesibukan yang diemban oleh para dosen baik dosen tetap maupun dosen tidak tetap, baik kegiatan internal UAI maupun kegiatan yang dilakukan diluar kampus UAI. Dosen tetap ada yang mempunyai jabatan struktural diluar jabatan resmi dia sebagai dosen tetap, hal ini sedikit mengganggu proses pembelajaran yang dilaksanakan. Kadang kala dosen tetap di sastra arab UAI dikaryakan untuk memegang kegiatan yang tidak menjadi tanggung jawab dia secara akademik, akan tetapi karena keterbatasan tenaga yang ada dosen yang bersangkutan terpaksa harus melakukan pekerjaan yang dimaksud begitu juga dengan dosen tidak tetap, yang berasal dari berbagai universitas yang ada di jakarta dan sekitarnya (UI, UIN, LIPIA, UNJ). Keberadaan dosen tidak tetap ini sangat dibutuhkan akan tetapi kesibukan personal dari masing-masing dosen tidak tetap diluar kampus UAI ikut mempengaruhi ketidakadilan maksimal mengajar bahasa arab di sastra arab UAI. Sementara lima orang mahasiswa atau sekitar $7.8 \%$ mahasiswa tidak menyatakan pendapatnya. Menurut analisa peneliti jumlah yang lima ini kalau kita adakan pendekatan khusus mungkin akan memilih tidak setuju, akan tetapi karena kekhawatiran yang ada dalam diri mereka kalau memilih tidak setuju akan berdampak kepada mereka, mereka lebih memilih pernyataan tidak berpendapat. 
Tabel 11: Persepsi mahasiswa terhadap pernyataan bahwa dosen mata kuliah memantau segenap tugas yang diberikan dan dikoreksi serta dikembalikan kemabali kepada mahasiswa

\begin{tabular}{|l|l|l|l|l|l|}
\hline & & Frekuensi & Persentase & Persentase valid & Persentase kumulatif \\
\hline Valid & Setuju & 28 & 43.8 & 43.8 & 43.8 \\
\hline & $\begin{array}{l}\text { Tidak } \\
\text { Berpendapat }\end{array}$ & 7 & 10.9 & 10.9 & 54.6 \\
\hline & Tidak Setuju & 29 & 45.3 & 45.3 & 100.0 \\
\hline & Total & 64 & 100.0 & 100.0 & \\
\hline
\end{tabular}

Dari tabel 11 diatas didapati data bahwa 28 orang mahasiswa atau sekitar $43.7 \%$ mahasiswa setuju dengan pernyataan yang menyatakan bahwa dosen MK kemahiran bahasa Arab memantau segenap tugas yang diberikan dan dikoreksi serta dikembalikan kembali kepada mahasiswa. Persepsi mahasiswa seperti ini merupakan gambaran yang ada di sastra arab UAI dimana hanya sekitar 28 orang mahasiswa dari 64 orang yang dijadikan sampel didalam penelitian ini yang menyatakan bahwa dosen yang mengajar mereka komit dengan tugas yang diberikan, memantau, mengoreksi dan mengembalikan tugas yang diberikan kepada mahasiswa, artinya hanya sekitar setengah dari dosen yang komit menggunakan standar pemberian tugas harian kepada mahasiswa. Sementara 29 orang mahasiswa atau sekitar $45.3 \%$ mahasiswa menyatakan tidak setuju dengan pernyataan yang menyatakan bahwa dosen MK kemahiran bahasa Arab memantau segenap tugas yang diberikan dan dikoreksi serta dikembalikan kembali kepada mahasiswa. Jumlah yang sangat besar memang, persepsi ini tentunya perlu di kroscek ulang kepada dosen yang bersangkutan, akan tetapi inilah dinamika yang ada dipendidikan tinggi kita di Indonesia termasuk di program studi sastra arab UAI. Kesibukan dosen diberbagai macam kegiatan kadang mempengaruhi tingkat kedekatan mereka dengan mahasiswa termasuk memantau bentuk-bentuk tugas yang diberikan. Idealnya satu tugas yang dibebankan kepada mahasiswa harus dipantau sejauh mana mahasiswa itu mengerjakan dengan mandiri, sejauh mana dosen mengoreksi dan sejauh mana dosen memberikan apresiasi dari pekerjaan yang sudah dikerjakan oleh mahasiswanya. Ini menjadi tanggungjawab kita bersama di sastra arab UAI. Sementara tujuh orang mahasiswa atau sekitar $10.9 \%$ mahasiswa tidak menyatakan pendapatnya. Menurut analisa peneliti jumlah yang tujuh ini kalau kita adakan pendekatan khusus kepada mereka, mungkin mereka akan memilih tidak setuju, akan tetapi karena kekhawatiran yang ada dalam diri mereka kalau memilih tidak setuju akan berdampak kepada mereka, mereka lebih memilih pernyataan tidak berpendapat.
VI. Analisa terkait persepsi mahasiswa tentang teknik evaluasi yang digunakan oleh dosen/pengajar mata kuliah kemahiran berbahasa bahasa Arab di program studi Sastra Arab, Universitas Al Azhar Indonesia. 
Dari tabel 12 dibawah didapati data bahwa 53 orang mahasiswa atau sekitar $82.8 \%$ mahasiswa menyatakan setuju dengan pernyataan yang menyatakan bahwa dosen MK kemahiran Bahasa Arab memberikan penilaian telah sesuai dengan standar kemampuan mahasiswa yang bersangkutan. Menurut analisa peneliti persepsi ini sangat erat kaitannya dengan pernyataan sebelumnya dimana dengan menilai mahasiswa secara profesional lewat penilaian harian, mingguan dan bulanan akan adil dan lebih dekat kepada kenyataan yang sebenarnya dan sesuai dengan kemampuan mereka, malah kita sebagai dosen ketika menemukan kenyataan ada beberapa mahasiswa tidak memeperlihatkan hasil yang memuaskan dari hari kehari, minggu ke minggu dan seterusnya, kita bisa mencarikan terapi dan solusi dari ketidakmampuan mereka terhadap kemahiran berbahasa yang lemah dari mereka. Tujuha orang mahasiswa atau sekitar $10.9 \%$ mahasiswa tidak menyatakan pendapatnya. Sementara empat orang mahasiswa atau sekitar $6.2 \%$ mahasiswa tidak setuju dengan pernyataan yang menyatakan bahwa dosen MK kemahiran Bahasa Arab memberikan penilaian telah sesuai dengan standar kemampuan mahasiswa yang bersangkutan.

Tabel 12: Persepsi mahasiswa terhadap pernyataan bahwa dosen kemahiran Bahasa Arab memberikan penilaian telah sesuai dengan standar kemampuan mahasiswa yang bersangkutan

\begin{tabular}{|l|l|l|l|l|l|}
\hline & & Frekuensi & Persentase & Persentase valid & Persentase kumulatif \\
\hline Valid & Setuju & 53 & 82.8 & 82.8 & 82.8 \\
\hline & $\begin{array}{l}\text { Tidak } \\
\text { Berpendapat }\end{array}$ & 7 & 10.9 & 10.9 & 93.7 \\
\hline & Tidak Setuju & 4 & 6.2 & 6.2 & 100.0 \\
\hline & Total & 64 & 100.0 & 100.0 & \\
\hline
\end{tabular}

Tabel 13: Persepsi mahasiswa terhadap pernyataan bahwa dosen memberikan nilai akhir adil dan tidak dipengaruhi kedekatan dengan mahasiswa, dan lain-lain

\begin{tabular}{|l|l|l|l|l|l|}
\hline & & Frekuensi & Persentase & Persentase valid & Persentase kumulatif \\
\hline Valid & Setuju & 50 & 78.1 & 78.1 & 78.1 \\
\hline & $\begin{array}{l}\text { Tidak } \\
\text { Berpendapat }\end{array}$ & 5 & 7.8 & 7.8 & 85.9 \\
\hline & Tidak Setuju & 9 & 14.1 & 14.1 & 100.0 \\
\hline
\end{tabular}




\begin{tabular}{|l|l|l|l|l|l|}
\hline Total & 64 & 100.0 & 100.0 & \\
\hline
\end{tabular}

Dari tabel diatas didapati data bahwa 50 orang mahasiswa atau sekitar $78.1 \%$ mahasiswa menyatakan setuju dengan pernyataan yang menyatakan bahwa dosen MK kemahiran bahasa Arab dalam memberikan nilai akhir adil dan tidak dipengaruhi kedekatan dengan mahasiswa, dan lain-lain. Menurut analisa peneliti persepsi mahasiswa seperti ini merupakan penilaian yang ideal karena sudah sewajarnya kita sebagai pendidik mengenyampingkan pendekatan personal ketika memberikan penilaian kepada mahasiswa yang kita ajar. Kedekatan antara mahasiswa dan dosen merupakan sebuah keharusan dalam proses pendidikan yang dilaksanakan dalam pendidikan, baik ditingkat pendidikan dasar, menengah maupun di perguruan tinggi. Kedekatan ini dimanfaatkan untuk memberikan motivasi kepada mahasiswa untuk belajar lebih giat. Akan tetapi ketika kedekatan mempengaruhi penilaian kepada mahasiswa, itu sangat mencederai keberhasilan sebuah pembelajaran. Lima orang mahasiswa atau sekitar 7.8\% tidak menyatakan pendapatnya. Sementara 9 orang mahasiswa atau sekitar $14.1 \%$ mahasiswa menyatakan tidak setuju ketika dinyatakan bahwa dosen MK kemahiran bahasa Arab dalam memberikan nilai akhir adil dan tidak dipengaruhi kedekatan dengan mahasiswa, dan lain-lain. Kenyataan persepsi mahasiswa ini perlu menjadi kajian kita para dosen di jurusan sastra arab UAI dimana masih ada penilaian dimata mahasiswa menyatakan bahwa ada dosen tidak memberikan nilai sesuai dengan standar penilaian ideal, ada beberapa dosen di mata mahasiswa memberikan nilai masih dipengaruhi dengan kedekatan antara dosen dengan mahasiswa. Masukan ini semoga memberi perubahan dalam sistem penilaian bahasa arab kepada mahasiswa dilingkungan sastra arab UAI pada khususnya.

\section{Saran dan masukan mahasiswa Sastra Arab, Fakultas Sastra UAI untuk dosen pengajar kemahiran berbahasa terkait penelitian}

Ketika ditanyakan secara umum pendapat mahasiswa Sastra Arab tentang perkuliahan kemahiran berbahasa bahasa Arab yang dilaksanakan di program studi Sastra Arab, Universitas Al Azhar Indonesia, serta saran yang membangun untuk perbaikan kedepan mata kuliah Bahasa Arab di Sastra Arab UAI, mahasiswa memberikan masukan sebagai berikut:

- Salah satu faktor yang mendukung keberhasilan pembelajaran bahasa Arab adalah lingkungan atau dalam bahasa Arab dinamakan 'biah arabiah', menciptakan lingkungan bernuansa Arab dan islami menjadikan mahasiswa lebih termotivasi untuk belajar bahasa Arab.

- Perlu ada peningkatan dalam pelaksanaan proses pembelajaran bahasa Arab di sastra Arab UAI, untuk kemahiran istima dimata sebagian mahasiswa dosen yang mengajar sudah cukup ideal dan sangat pengertian dengan keadaan mahasiswa dalam perkuliahan, apalagi dengan kebijakan kampus dan prodi yang mendatangkan seorang native speaker mengajar memberikan nuansa dan motifasi tersendiri dalam pembelajaran yang dilaksanakan.

- Untuk tingkat kehadiran dosen, mahasiswa sangat berharap agar dosen hadir dan masuk keruang pertemuan ontime dan keluar ontime agar tidak memotong waktu istirahat dan kelas sesudahnya. 
- Disamping keterlambatan dan keluar yang sedikit bermasalah di Sastra Arab UAI, mahasiswa juga melihat kehadiran dosen yang tidak maksimal di perkuliahan yang sudah dijadwalkan, dosen terkadang tidak bisa masuk mengajar dengan alasan dan kesibukan tertentu yang seharusnya tidak harus mengorbankan jadwal kuliah yang sudah disepakati diawal.

- Mahasiswa mengharapkan agar para dosen juga harus berusaha untuk meningkatkan kemampuan mereka dalam bidang kompetensi keilmuan, metodologi mengajar, interaksi dengan mahasiswa dan lingkungan guna untuk meningkatkan susana pembelajaran yang interaktif.

- Mahasiswa juga sangat berharap bimbingan penuh dari para dosen khususnya terkait dalam dalam memberi dukungan, motivasi serta arahan bagaimana mahasiswa dapat mengembangkan kemahiran berbahasa arab mereka, dan ke lapangan kerja mana mahasiswa dapat diarahkan untuk masa depan mereka.

- Untuk tugas yang diberikan, baik harian, mingguan ataupun tugas berkala lainnya, mahasiswa sangat berharap agar dosen menyediakan waktunya untuk membahas kembali tugas-tugas yang telah diberikan kepada mahasiswa. Apresiasi dalam bentuk penilaian dan diskusi serta membedah kembali tugas yang diberikan akan memberikan pengaruh tersendiri kepada mahasiswa yang sudah dengan sadar mengerjakan tugas yang diberikan oleh dosen.

\section{KESIMPULAN}

Dari penelitian ini dapat diambil kesimpulan sebagai berikut:

1. Dalam pembelajaran bahasa Arab, mahasiswa prodi Sastra Arab UAI memiliki persepsi yang positif serta kesadaran akan pentingnya bahasa Arab dalam kehidupan mereka sehari-hari, serta tujuan pembelajaran bahasa Arab yang dikembangkan oleh prodi sastra Arab UAI. Disamping untuk menjadi seorang penerjemah yang handal, mahasiswa sastra
Arab UAI juga dihantarkan nuntuk menguasai kemahiran bahasa yang empat dengan baik dan secara seimbang.

2. Materi atau bahan ajar yang digunakan oleh dosen pengampu mata kuliah kemahiran bahasa Arab di Prodi Sastra Arab UAI sudah sesuai dengan standar dan bisa mengantarkan mahasiwa kepada keahlian berbahasa yang mereka inginkan.

3. Penerapan metodologi pengajaran kemahiran berbahasa oleh dosen pengampu mata kuliah kemahiran berbahasa bahasa Arab di program studi Sastra Arab cukup sistematis sesuai SAP yang digariskan, serta mengacu kepada penggunaan bahan ajar yang digunakan.

4. Dosen pengajar mata kuliah kemahiran berbahasa bahasa Arab di program studi Sastra Arab sudah kemampuan mengajar bahasa Arab cukup baik. Penampilan dan komunikasi personal dosen dengan mahasiswa cukup positif sehingga ikut mendorong dan memotivasi mahasiswa untuk mempelajari kemahiran bahasa Arab dengan baik. Situasi itu dibarengi pula dengan komitmen dosen untuk menegakkan disiplin menegakan aturan yang berlaku di UAI.

5. Untuk evaluasi yang digunakan oleh dosen, para dosen sudah menerapkan proses penilaian secara adil dan tidak dipengaruhi kedekatan dengan mahasiswa dan telah sesuai dengan standar kemampuan mahasiswa yang bersangkutan.

\section{B. Saran dan Rekomendasi}

1. Perlunya perhatian dan dukungan kebijakan yang lebih komprehensif dari pimpinan UAI, terkait pembelajaran mata kuliah kemahiran Bahasa Arab di UAI.

2. Perlunya ruang khusus bagi mahasiswa sastra Arab UAI untuk menciptakan 'biah arabiah' (lingkungan yang bernuansa Arab)..

3. Perlunya dukungan dan fasilitasi UAI bagi pengembangan kemampuan dosen dan bahan kemahiran bahasa Arab untuk 
mengikuti pelatihan-pelatihan serta peningkatan kompetensi dosen.

\section{Website:}

\section{DAFTAR PUSTAKA}

\section{Buku Referensi}

- Prof. Dr. Aziz Fahrurrazi, MA, Erta Mahyudin, M. Pd, Pembelajaran Bahasa Arab, Direktorat Jendral Pendidikan Islam, DEPAG RI, 2009

- Ahmad Fuad Effendy, Metodologi Pengajaran Bahasa Arab, 2005, Penerbit Misykat Malang.

- Al-Khuliy, Muhammad Ali. 2003. Model Pembelajaran Bahasa Arab. Terjemahan Asālību Tadrīsi Al-Lughah Al-'Arabiyyah oleh Yayan Nurbayan et.al. Bandung: Pusat Studi Islam dan Bahasa Arab Universitas Pendidikan Indonesia.

- Makmun Abin Syamsududin, Psikologi Pendidikan, Bandung, Remaja Rosdakarya, 1990

- Direktorat Jenderal Pendidikan Dasar dan Menengah Departemen Pendidikan Nasional. Pedoman Khusus Pengembangan Silabus dan Sistem Penilaian Berbasis Kompetensi Mata Pelajaran Bahasa Arab : Jakarta, 2003

- Ainin, M., M. Tohir, Imam Asrori. Evaluasi dalam Pembelajaran Bahasa Arab: Malang: Misykat, 2006

- Subiyakto, Sri Utari dan Nababan. Metodologi Pengajaran Bahasa. Jakarta: P.T Gramedia Pustaka Utama, 1993.

- Tarigan, Henry Guntur. Metodologi Pengajaran Bahasa (Suatu Penelitian Kepustakaan). Jakarta: Depdikbud, Direktorat Jenderal Pendidikan Tinggi. 1989.

- Faisal Hendra, Nur Hizbullah, Hasil penelitian: Persepsi Mahasiswa Universitas Al Azhar Indonesia terhadap Mata Kuliah Umum Bahasa Arab di Universitas Al Azhar Indonesia, UAI 2010

- Sastra Arab, Fakultas Sastra, UAI: Borang program Studi: Akreditasi 2009 